\title{
Pushing the entrepreneurial prodigy: Canadian Aboriginal entrepreneurship education initiatives ${ }^{1}$
}

Laura Elizabeth Pinto

Faculty of Education, University of Ontario Institute of Technology, Oshawa, Canada

Levon Ellen Blue

School of Education and Professional Studies, Griffith University, Mt. Gravatt, Australia

Draft version of paper. Citation: Pinto, L.E. \& Blue, L.E. (2015). Pushing the entrepreneurial prodigy: Canadian Aboriginal entrepreneurship education initiatives. Critical Studies in Education. http://dx.doi.org/10.1080/17508487.2015.1096291

\begin{abstract}
Globally, neoliberal education policy touts youth entrepreneurship education as a solution for staggering youth unemployment, a means to bolster economically depressed regions, and solution to the ill-defined changing marketplace. Many jurisdictions have emphasized a need for K-12 entrepreneurial education for the general population, and targeted to youth labelled "at risk." The Martin Aboriginal Education Initiative's Aboriginal Youth Entrepreneurship Program (AYEP) has been enacted across Canada. This paper applies critical discourse analysis to a corpus of texts, exposing how colonial practices, deficit discourse and discursive neoliberalism are embedded and perpetuated though entrepreneurial education targeted at Aboriginal students via AYEP.
\end{abstract}

Keywords: entrepreneurship education; entrepreneurial education, education policy, Aboriginal education; Indigenous education

\section{Introduction}

Globally, entrepreneurship education (EE) is touted as a solution for staggering youth unemployment, a means to bolster economically depressed regions, and solution to the ill-defined "changing marketplace" (Pinto, 2014). Non-governmental organizations such as OECD advocate for its inclusion in formal education (Coduras \& Outio, 2013), and the European Union identified entrepreneurship as one of the eight competences for lifelong learning (European Communities, 2007). EE takes many forms - formal (credit courses and diploma programs), informal (e.g., mentorship) and non-formal (e.g., noncredit courses, tutorials and self-study programs) education; and has been targeted to children, youth and adults. EE goals include persuading individuals to take up selfemployment as a career by inculcating a specific curricular canon (accounting, financial management, marketing, and venture plans) purported to lead to entrepreneurial success (Jones, 2014; Pinto, 2014).

International interest in promoting entrepreneurship among Indigenous peoples has been driven by failures of "passive welfare" systems, and under the assumption that entrepreneurship would result in autonomous participation in mainstream economic systems (Hindle \& Moroz, 2010). Indigenous entrepreneurship is "activity focused on new venture creation or the pursuit of economic opportunity, or both, for the purpose of diminishing Indigenous disadvantage through culturally viable and community acceptable wealth creation" (Hindle \& Moroz, 2010, p. 372). Yet, critics have argued that conventional EE reflects colonial approaches to assimilation that fail to disrupt hegemonic power imbalances when targeted to Indigenous peoples (Banerjee \& Tedmanson, 2010; Revely \& Down, 2009). Does Indigenous EE help to liberate these "Others" on their own terms? Or are these programs "civilizing missions" that attempt to impose Eurocentric practices and values in the form of "tools and opportunities" for "them"?

\footnotetext{
${ }^{1}$ This is a reworked and expanded version of a paper delivered at the International Association for Intercultural Education/American Educational Studies Association (IAIE/AESA) joint Conference, 1 November 2014.
} 
This research is specifically concerned with EE in formal education settings for teen-aged First Nations, Métis and Inuit (here after Aboriginal) learners. Many jurisdictions, including several Canadian provinces, have emphasized a need for K-12 EE for the general population, and for youth labelled "at risk" (Pinto, 2014). In Canada, the Martin Aboriginal Education Initiative (MAEI) is a special interest group founded by former Canadian Prime Minister Paul Martin. MAEI's mandate is to "improve the social and economic strength of Aboriginal people" by providing them with "tools and opportunities they need to succeed" (www.maei-ieam.ca). In 2011, MAEI developed the Aboriginal Youth Entrepreneurship Program (AYEP). This specialized program was designed for Aboriginal learners (in public schools on- and off-reserve) consisting of curriculum materials (textbooks and pedagogies) for Grade 11 and 12 secondary school credit courses. Teachers complete a training program in order to use the materials.

The objective of this paper is to explore ways in which discourses operate in AYEP's enactment to determine how they measure up against postcolonial ideals. In doing so, the research highlights the effects of neoliberal education policy and practice relating to Aboriginal students. We use critical discourse analysis (CDA) to a corpus of texts relating to AYEP program aims, structure and content. Analysis uncovers how AYEP embeds colonial practices and perpetuates inequities through discursive practices and program features by emphasizing the benev(i)olent heroes who championed the program, and in the discursive construction of the fictive Aboriginal learner and entrepreneur. Exposing the fictive constructions created by discourses is important because, as Jones (2014) found, these constructions standardize education in ways that normalize hegemonic practice. The social practices stemming from the constructions have real-world consequences because they shape relations inside and outside of school. The constructions suggest serious shortcomings and point to program design changes necessary to decolonize EE for AYEP participants in Canada, and similar programs elsewhere.

\section{Policy and Program Context}

Neoliberalism has dominated education policy and practice since the 1990s (Pinto, 2012; Wright, 2012) and drives the current global emphasis on EE for both the general population and Indigenous and Aboriginal peoples (Hindle \& Moroz, 2010). EE has been heralded as "a cure for youth joblessness" (Pinto, 2014). Using "crisis" to justify education policy is a commonly-practiced political tactic in neoliberal regimes (Nordin, 2014; Pinto, 2012). Canadian politicians and journalists used crisis-based arguments, insisting the "urgent need" for children's EE will take care of Canada's lacklustre education ranking in Ernst \& Young's G20 Entrepreneurship Barometer, and solve Canada's 16.5\% youth unemployment rate (Pinto, 2014). These sorts of arguments remain uncontested not only in Canada and internationally European Union (Coduras \& Outio, 2013; Jones, 2014), despite an absence of evidence to support claims (Pinto, 2014).

Neoliberal discourses are intimately tied to securing power and exploiting economic and political resources through education. Rhetorical constructs in Ontario's EE curriculum policy reflect neoliberalism defined by Eurocentric practices that marginalize Aboriginal learners to the fringes of educational institutions (Cherubini, 2010; Subedi, 2013) both on- and off-reserve. Their central role in the reproduction domination and subordination of Aboriginal learners through EE colonial "fantasies of empowerment" (Wright, 2012, p. 279) is punctuated by deficit thinking and illusions of meritocracy.

Many Canadian provinces (Alberta, British Columbia, Manitoba, Nova Scotia, Ontario and Saskatchewan) introduced high school EE courses in the 1990s. By 2014, 
provinces and special-interest groups introduced curriculum policy emphasizing entrepreneurship for younger learners in grades 4-12 (Pinto, 2014). These policies require teachers to incorporate entrepreneurial themes across the curriculum, and the senior-level high school courses remain electives (Pinto, 2014).

While distinct from provincial curriculum, AYEP shares provinces' commitment to entrepreneurship and has been enacted in partnership with school districts and governments so that it is aligned to government-sanctioned policy. In 2014, MAIE claimed it had been enacted in 44 Canadian schools, reaching over 700 students (www.maei-ieam.ca). Enactment occurred in partnership with provincial Ministries of Education, resulting in credits towards provincially-awarded secondary school diplomas.

\section{Envisioning a postcolonial ideal in education}

Postcolonial approaches to scholarship attempt to disrupt the neoliberal ideologies entrenched in all facets of education, especially the dominance of Eurocentric knowledge and cultural production (Kanu, 2003). Postcolonialism represents a spectrum of conceptions that share several common features: a position against Eurocentric imperialism, questioning of underlying individual, academic and political assumptions, and the goal of social justice for those oppressed by Eurocentric practice (Kanu, 2003).

Postcolonialism is an ideal not yet achieved (Battiste, 2013). Rather, pervasive Eurocentric models of education remain rife with intellectual and material violence, part of the "benev(i)olent 'gift"' (Hickling-Hudson, 2011, p. 462) of dominant groups within neoliberal regimes. Eurocentric models represent colonial education that is endemic in society (Brayboy, 2005). Within colonial education, Whiteness exists as "the de facto 'norm' and those who are not white or do not 'act white' are seen as not normal substandard on several levels" (Revilla, White \& Holmes, 2004, p. 285). Cultural dispossession and assimilation are central to colonization and exist against the backdrop of Whiteness as the only natural position in which fear of the "other" as different and deficient emerges. Whiteness allows exclusive rights to freedom, and to the ability to benefit from these rights, amounting to (invisible) White privilege (Ladson-Billings, 1998). Given the role that Whiteness and White privilege play as the predominant culture in schools (Castagno \& Brayboy, 2008), they perpetuate colonial education and are therefore central to our inquiry.

Analysis of White privilege must include examination of white supremacy (Leonardo, 2004). Supremacy (Gillborn, 2005; Leonardo, 2004) rejects the superficial conception associated with "extreme racialized politics" (Gillborn, 2005, p. 491).

Rather, White supremacy is a "European or western way of doing things has both moral and intellectual superiority over those things non-western" (Brayboy, 2005, p. 432).

White supremacy is one of the central tenants of Brayboy's (2005) conceptual outline of TribalCrit, in which its invisibility and "naturalness" (p. 432) lead to its hegemonic power and centrality in shaping contemporary education policy and practice. This research attempts to identify how White privilege and supremacy operate in Canada in relation to Aboriginal youth.

When viewed as material property, Whiteness provides material and symbolic privileges (Ladson-Billings, 1998). Examples include access to education, and choice of places in which to live. In symbolic terms, property includes conceptions of beauty or intelligence that not only are tied to Whiteness, but those that implicitly exclude "Redness" - therefore reinforcing White supremacy (Brayboy, 2005). In education, property can operate both materially (e.g., funding) and symbolically (e.g., overt and hidden curriculum, educational outcomes) (Ladson-Billings, 1998).

Postcolonial scholarship attempts to overcome violence and supremacy by destabilizing taken-for-granted categories, representations, and truths with the goal of 
more equitable education via critiques of hegemonic systems and structures. This approach necessarily involves identifying and dismantling colonial forms of education through concerted decolonization practices. The project of decolonizing education has a goal of sovereignty and self-determination (Castagno \& Brayboy, 2008) throughwhich Aboriginal peoples might regain control of educational practices that were severed from them upon first contact (Battiste, 2013; Brayboy, 2005).

Colonial practices that aim to assimilate jeopardize authentic delivery of Aboriginal epistemology (AE), indigenous knowledge (IK) (Battiste, 2013; Brayboy, 2005; Cherubini, 2010) tarnish the calls for self-determination (a set of human rights precepts grounded in the idea that all are equally entitled to control their own destinies, achieved by dismantling legacies of empire, discrimination, suppression of democratic participation, and cultural suffocation, Napoleon, 2005). In education, selfdetermination has to do with not only incorporation of IK into schools, but a transformation of institutional structures to disrupt colonial structures of inequality that would ultimately lead to tribal sovereignty (Battiste, 2013; Brayboy, 2005).

Culturally responsive schooling (CRS) is an approach to decolonization through learner empowerment that privileges marginalized epistemic, cultural, and linguistic identities (Castagno \& Brayboy, 2008; Cherubini, 2010). CRS must respect IK and meaningfully represent $\mathrm{AE}$ in order to foster the authentic identity of Aboriginal youth. In its absence, the disconnect between the material realities of the world and Aboriginal students' lived experiences can result in students' failure to "learn to critique their place in the world as well as the intersection of power and privilege that creates inequities and oppression" (Subedi, 2013, p. 626; also Castagno \& Brayboy, 2008). Yet, commitment to CRS can reclaim the material property of curriculum in ways that empower Aboriginal learners and communities (Castagno \& Brayboy, 2008).

A decolonizing, CRS framework would consist of 3 critical approaches: antiessentialism, contrapuntal readings, and ethical solidarity (Subedi, 2013), while addressing Brayboy's (2005) TribalCrit tenants and recommendations. Antiessentialism takes on and takes down monolithic portrayals of groups. When Aboriginal learners are represented monolithically, curriculum and pedagogy fail to recognize the ways in which intersectionality occurs (operating at the intersection of two or more categories of identity, such as Aboriginal status and/or gender and/or class, Delgado, 2011).

Aboriginal youth often negotiate bicultural identities between beliefs, relationships, and practices of the curriculum and their traditional teachings and worldviews (Cherubini, 2010). As such, many experience bivalent modes of collectivity (Arnot, 2006; Fraser, 1997), suffering socioeconomic maldistribution and cultural misrecognition simultaneously, where neither of these can be reduced to an effect of the other. Aboriginal learners in Canada have found it necessary to adjust their socio-emotional behaviours to accommodate the realities of mainstream education, which has perpetuated a sense of hopelessness of experiencing an authentic education (Cherubini, 2010). An anti-essentialist approach to Aboriginal entrepreneurship would take this spectrum into account, rather than offer a one-size-fits-all curriculum that incorrectly implies that a single Aboriginal perspective exists (Brayboy, 2005; Subedi, 2013).

The second approach, contrapuntal readings, departs from traditional ways of framing comparative analysis by explicitly focusing on questions of colonization and imperialism in the production of knowledge and power relations (Subedi, 2013). Colonial curriculum silences these relationships (Brayboy, 2005). For example, a colonial case study or profile of an Aboriginal entrepreneur might celebrate that person's success, but would not take seriously (or conceal) issues of racism, systemic barriers, or other acts of colonial violence the entrepreneur experienced. ${ }^{1}$

The goal of ethical solidarity is to develop emancipatory consciousness by promoting cross-cultural dialogue, all the while recognizing the complications of power and White privilege in allowing voices to emerge and be heard (Subedi, 2013; see 
Boler, 2004, for diverse perspectives on challenges and realities). Ethical solidarity's investment in the politics of changing social norms would be consistent with calls for transformative action towards a critical conception of self-determination (Battiste, 2013; Brayboy, 2005). Processes ${ }^{2}$ must engage privileged learners in reflection about privilege and oppression with the goal of fostering collective responsibility for complicity in social inequality, (Brayboy, 2005; Cannon, 2013) with an overt component of activism (Brayboy, 2005).

\section{Approach to Discourse Analysis}

Our analysis used a 25,000-word textual corpus. First, we included AYEP website content. Second, we included slide presentations from school districts who enacted AYEP: Ontario's Toronto District School Board (TDSB) (2014) and Alberta's Father Patrick Mercredi Centre (henceforth referred to as Mercredi, 2013). The slides provided local examples of program content and student work. We included a Band publication (Tailfeathers, 2014) because it contained additional AYEP details. Finally, we conducted a Canadian Newsstand Database search between January, 1, 2011 and September 1, 2014 using the keywords aboriginal youth education and entrepreneurship. We eliminated 3 of the resulting 35 articles due to irrelevance. Eight were national (National Post, Globe \& Mail, and Canadian Press wire service), while the remainder were local papers in Ontario, British Columbia, Nova Scotia, Saskatchewan, and Alberta. Press coverage is relevant to the study of AYEP, since media play an important role in framing public understandings as political actors who influence policy production and consumption (Pinto, 2013). We acknowledge, however, that as a hegemonic institution, the mainstream media filters messages. We hope that the inclusion of other corpus artefacts balance media perspectives and offer a more holistic view of AYEP's enactment.

We requested access to official AYEP materials beyond those available on the website, specifically interested AYEP textbooks produced by international publisher Nelson. However, Nelson indicated the textbooks were not for sale, and only distributed through AYEP. ${ }^{3}$ An AYEP director informed us that copyright prevented the distribution of any materials outside of those directly involved in program delivery. Without access, we cannot comment on the substantive nature of the textbook content. Rather, we rely on available textual materials that provide perspectives about AYEP and its enactment.

We analyzed texts using CDA. Discourse is "a practice not just of representing the world, but signifying the world, constituting and constructing the world in meaning" (Fairclough, 1992, p. 64). As such, CDA exposes of the role of language, language use, and discourse in the (re)production of dominance and inequity (van Dijk, 1993). Discourses in Aboriginal EE policy and media coverage are political constructs, constantly made and remade, and transmitted to students and teachers who rely on curriculum documents/resources to guide their practice in schools. Alh and Marlow (2012) emphasized the immense need for CDA of EE policy and texts due to its strong ideological elements that reinforce hegemonic structures. Specifically, dominant neoliberal discourses that shape entrepreneurship remain so socially accepted that they are taken for granted and thus become invisible (Jones, 2014). While Jones' (2012) and Ahl and Marlow's (2012) work focused on gender, we view Aboriginal entrepreneurs as a separate bivalent collective that face some similar issues.

We approached our analysis in several phases, following van Dijk's (1993) emphasis on rhetoric, and Ahl and Marlow's (2012) 5 stages: (1) content analysis to identify objects and subjects, their emphasis and frequencies; (2) analysis of attempts to persuade; (3) identification of subtle and overt ideologies; (4) linguistic analysis 
including identification of literary devices; and (5) discourse analysis. We focused on those that most clearly exhibited the discursive properties of the exercise of dominance (van Dijk, 1993), and identified the predominant discourses, grounded against our theoretical framework.

\section{Discursive Constructions}

We identified 3 discursive contructions: the benev(i)olent heroes, the fictive Aboriginal student, and the fictive entrepreneur. Discourses are identified and discussed within these constructions, contributing to the understanding of how the Canadian EE context perpetuates colonial-assimilationist practice.

\section{Constructing benev(i)olent heroes through colonial/assimilationist discourses}

The vast majority of the corpus focused on conveying the narratives of the White, male "heroes" who championed the AYEP program, including financial and energy companies (Bank of Nova Scotia, Royal Bank, Japan Canada Oil Sands, Potash Corp., Enbridge). The inclusion of Japan Canada Oil Sands is interesting in light of recent controversies surrounding their allegedly exploitative towards Aboriginal communities (e.g., Friedel, 2008; Krupa, 2012).

The prominence of former Canadian Prime Minister Paul Martin (a White man) and the corporations reinforced hegemonic power. In the 25,000-word corpus, "Martin" appeared 330 times, "student(s)" 216 times (with only 4 students quoted, the remainder referring to "students" as a monolithic object of policy enactment), "Bank of Nova Scotia" or "Scotiabank" 37 times, and "teacher(s)" a mere 26 times, reinforcing marketization. The portrayal of the official "story" in the press, AYEP website, and school-produced materials overtly re-centred White privilege by placing nonAboriginals at the centre of the discussion. The issue of White-driven advocacy is problematic in itself, since it can become an instrument of domination that undermines Indigenous self-determination and autonomy (Keddie \& Niesche, 2012) and thereby reinforce supremacy. At the same time, coverage exclusively emphasized the generosity of individual and corporate financial donations, time and effort. AYEP's official materials frequently (albeit vaguely) mentioned community collaboration in resource development, with the implicit assumption that Aboriginal communities shared the same priorities and goals as MAEI. To a lesser degree, newspaper articles described Aboriginal community involvement, including some positive quotations from community members.

The corpus framed Martin as a hero - not a single item in the corpus called his intentions, reasoning, or narrative into question. Rather, it relied on colourful language and tropes to describe his benevolence in forming AYEP. For example, "Watch the fire in Paul Martin's eyes...listen to the sadness in his voice. And don't ignore the hopeful determination in his spirit... [he is] a man on a mission" (Kennedy, 2011a; 2011b, 2011c). Kennedy (2011a; 2011b, 2011c) noted, "at age 73, he is a millionaire who could be relaxing in retirement," but instead committed himself to helping Aboriginal peoples through MAEI/AYEP and received the first Award for Excellence in Aboriginal Relations."

Martin's quotes reflected an astounding lack of cultural sensitivity. The roots of his benevolence were attributed to the following story: Martin recalled that his "old buddies" in the working-class city of Windsor, Ontario talked about how they would "conquer the world" in adulthood. Aboriginal friends he made in northern Canada had a "lack of hope," a result of conditions in which they lived, leaving them "not as excited about their future prospects as he was." He concluded that a Canadian dream of 
conquering the world was "true for the Irish and the Italians and everybody else who immigrated to this country, why isn't it true for the first peoples?" (Kennedy, 2011a; 2011b, 2011c).

"What Aboriginal Canada needs is a robust middle class" who wants to "conquer the world," Martin said (Kennedy, 2011a; 2011b, 2011c). The imagery of "conquering" for personal gain (achieving "middle class" status) as an unquestioned and universal goal is in direct opposition to AE. Martin's pondering about why Aboriginal peoples would not share the "truths" of Irish and Italian immigrants suggests a lack of awareness of how Eurocentricity and White privilege operate. The narrative appears rife with the "scent of the assimilationist practices imposed upon Aboriginal peoples in the not-so-distant past" noted by Cherubini (2010, p. 15) and consistent with Keddie and Niesche's (2012) observations that White advocacy can be ethnocentric and paternalistic in purporting to know what is best for Aboriginal people contributing to White supremacy.

Martin allegedly got the idea for AYEP from a 20-year-old American program operating "in inner-cities where minority students...were encouraged to study and pursue business ventures" (Schumacher, 2008; "Macgregor, 2008). Martin and his associate, Carlana Lindeman, reputedly visited New York City and Los Angeles, California where Lindeman completed the course for teachers and "returned an enthusiast" (Macgregor, 2008). This narrative failed to acknowledge problems associated with the appropriation of polices/programs to completely different circumstances (Lingard, 2010). It failed to address issues of curriculum-as-property and the way in which supremacy was reinforced through the power of White program sponsors.

The narratives just described reflected discursive colonization: "a multifaceted phenomenon that intertwines with political and economic institutions to incorporate a wide range of actors" (Revely \& Down, 2009, p. 162). Colonial discourses typically privilege White, Eurocentric experiences, beliefs, and histories, while silencing perspectives on the historical factors that led to existing power distribution and supremacy (Subedi, 2013). This was evident in the proportion of the corpus devoted to the Martin and the corporate partners. That the majority of corpus is media may account for editorial choices on what makes a "better" or newsworthy story, possibly trading on Martin's prominent name.

While Martin's and the corporate sponsors' intentions may be commendable, their rhetorical framing as heroes and culturally insensitive statements reinforced White privilege and supremacy. Rather than a focus on Aboriginal communities and individuals, the benevolent sponsors dominated media coverage. Were the favourable reactions to AYEP representative of the community? Were community members free to express their views? Cherubini (2010) found that education systems had been perceived by Aboriginal community members as an "agent of their oppression and the source of their suspicion" (p. 16) - a precarious socio-political position. The risk of public perception fallout should Aboriginal communities resist such high-profile benev(i)olence might leave them unable to speak out.

Beyond the cultural insensitivity described, the corpus also revealed a reliance on problem stories as a tool of discursive colonisation. Problem stories convey bleak, hopeless conditions in Third World societies in comparison to Western industrialized societies as progressive and democratic (Subedi, 2013). Quotes attributed to Martin repeated comparisons between Aboriginal peoples of Canada and oppressed groups elsewhere. He explained that "the problems" of Africa and Canadian Aboriginal peoples "are similar" (Kennedy, 2011 a, b,c; Macgregor, 2008). He likened the plight of Canadian Aboriginal youth to inner-city American youth (Macgregor, 2008). While it may be the case that the groups Martin described share a position of oppression, it was presumptuous to make such comparisons in the absence of full context, especially given 
the unique historical events circumstances that Aboriginal peoples in Canada have endured (e.g., Cherubini, 2010; Battiste, 2013). The discourse reduces issues to a "distinction between good and bad culture(s) and civilized and uncivilized cultural practice(s)" (Subedi, 2013, p. 624). AYEP's civilizing mission and practices become the "solution" to the "problem," rather than a postcolonial approach that would necessarily re-centre program design and features from an Aboriginal perspective and overtly challenging Eurocentric practices as recommended by Brayboy (2005).

Benevolence on the part of the program's champions accentuated AYEP's neoliberal approach to defining "necessary" skills that would redeem Aboriginal learners so they can become contributors to the market-driven economy. It was "an intention that may not necessarily be too strikingly different from the assimilationist colonial practices of years gone by" (Cherubini, 2010, p. 15). Absent from these colonial-assimilationist practices were ways in which students or teachers might be prejudicially perceived in their own communities as products of colonial education systems (Cherubini, 2010). Elsewhere, students have been subject to the label "Red Apple" (Cherubini, 2010, p. 17), ${ }^{4}$ and found themselves alienated from their communities. This is consistent with research that revealed how EE reproduced inequality (for example, Australian Indigenous entrepreneurs who struggled to fit into a White business world experienced alienation from their Indigenous peers, Revely \& Down, 2009). The root of such alienation rests in the neoliberal "civilizing mission" that denies IK, and forces Aboriginal learners to assimilate the benev(i)olent gift of AYEP.

\section{Constructing the fictive Aboriginal student through deficit discourses}

All forms of EE construct a "fictive student" (Jones, 2014): the student-asvisible-Other to which the curriculum-as-property is addressed. Such constructions are deemed fictive because no real reasons exist for their portrayal, yet they justify distain for the "real" students who do not measure up (Jones, 2014) to the invisible norm of Whiteness. EE, including AYEP, tends to accumulate White privilege via symbolic capital linked to fictive versions of the mainstream, neoliberal entrepreneur (Jones, 2014) - an approach in direct opposition to postcolonialism's stance against Eurocentric imperialism. This symbolic capital (re)produces the fictive student (Jones, 2014). Inequity arises when students are restricted in their ability to convert their own symbolic and cultural capital into narrowly-defined success outcomes of a program (Jones, 2014).

The corpus repeatedly reduced Aboriginal learners to purely economic constructs consistent with neoliberalism: "aboriginal youth are the fastest growing segment of the population and will be key drivers of the Canadian economy" (Cardston Temple City Star, 2014, Hoekstra, 2011; National Post, 2011), and "First Nations youth are the largest potential source for new entrants in the work force to replace baby boomers" (Hoekstra, 2011). Martin argued: "not only is there a moral imperative to correct this inequity, it makes business sense" (Hoekstra, 2011). This reduced Aboriginal learners to dehumanized "goals of action" rather than "agents of action" (Fairclough, 1992), a means to an end (driver of the economy), not citizens.

Deficit discourses emerge when monocultural and essentialist conceptions of norms dominate leading to White supremacy. They represent the Other as lacking "better" cultural values responsible for underachievement (Subedi, 2013) andattributing failure to deficiencies in students that are "corrected" by education. Other funds of knowledge, practices, and customs are considered deficient (Brayboy, 2005; Subedi, 2013). This was overtly evident in a quote attributed to Martin: "the program is to pave over a gap in the First Nations economy: a lack of local knowledge" and Aboriginal communities are "sitting on the resources the world wants. Their success in accessing and developing those resources for the benefit of their own people will depend in part on how well they know the business world" (National Post, 2013). 
Deficit discourses have been historically complicated by neoliberal ideology in Canadian education policy (Cherubini, 2010). Narrow definitions of "success" reflected in AYEP are "based on ethnocentric understandings that consider mainstream postcolonial knowledge and standards of living to be the defining understandings of these principles for all peoples" (Cherubini, 2010, p. 14). Ontario education policy has historically reinforced a "dangerously negative stereotype of Aboriginal peoples" (Cherubini, 2010, p. 13) couched in deficit thinking. While students received limited mention in the AYEP corpus compared to others, they were reduced to a monolithlic group about which "failure" statistics were repeatedly reported (high drop-out rates, and low post-secondary enrolment/completion) - a problem also noted by Brayboy (2005) elsewhere. These constant references to lower academic and economic achievement amplified underprivileged status and contributed to social exclusion of the fictive Aboriginal student, consistent with others' findings (Cherubini, 2010; Jones, 2014) and reinforce White supremacy (Brayboy, 2005).

Though AYEP claimed to recognize Aboriginal students' unique educational needs, TDSB (2014) and Mercredi (2013) described highly Eurocentric practices lacking cultural sensitivity. Mercredi (2013) used Who Wants to be a Millionaire, a competitive trivia game based on a popular television quiz show, as a featured pedagogy that included a picture of the program's logo. One is left wondering how this could possibly reflect a CRS approach to Aboriginal EE given that it is a highly Eurocentric media reference, with a fast-paced, unreflective and competitive nature inconsistent with reflective AE.

Additional pedagogies reflected colonial-assimilationist forms of expression. First, TDSB's (2014) "business clothing" component on how to fashion oneself in conventional, Western apparel such as suits embodied deficit discourse in the assumption that the fictive Aboriginal learner's clothing is inadequate. The implication is that that if learners assimilate and develop certain entrepreneurial behaviours ("conventional" business clothing, which reflects colonial discourse) prescribed in the curriculum, then any systemic barriers would be automatically overcome.

Second, TDSB (2014) featured the preparation of an "elevator pitch" (a "pitch" to persuade the listener to accept or invest in a business idea during the time the listener would be a captive audience in an elevator ride). While the elevator pitch is common in business education, it reflects a particular rhetorical style: fast paced, succinct, aggressive. By definition, the elevator speech is opportunistic - it presumes that the listener must endure the speaker's persuasion attempt since nobody can exit a moving elevator. Again, this strategy appears contrary to AE that would entail more reflective and thoughtful approaches to (inter)action, and respect for others through relationshipbuilding over time (Brayboy, 2005; Castagno \& Brayboy, 2008).

Third, both TDSB (2014) and Mercredi (2013) emphasized students' presentation of their business idea to Scotiabank - with the promise that a "good" business idea would result in a $\$ 500$ seed grant. Power is placed squarely in the hands of bankers to judge and distribute money. These are consistent with features of colonized education that "favored ways of speaking and acting, as well as favoured conceptions of knowledge of the Other, are the constitutive elements of such discourse structures, which govern not only student life chances but also such matters as who can speak, about what, and to whom" (Rizvi, 2005 quoted in Subedi, 2013, p. 622; also, Brayboy, 2005). The strategy also emphasized individual financial gain over community benefit, also at odds with IK (Battiste, 2013; Brayboy, 2005), in which resource sharing is expected and placing individual gain above that of others is at odds with community values (Brayboy, 2005; Brimble \& Blue, 2013). 


\section{Constructing the fictive entrepreneur through neoliberal discourses}

Conventional modes of EE reflect a highly Eurocentric point of view that privileges Whiteness, with non-negotiable emphasis on rationality, individualism, marketized notions of "success" and "prosperity" tied to wealth (Welter, Brush, \& De Bruin, 2014), and a notable absence of questioning of structures that typically oppose equity (Pinto \& Coulson, 2012). This construction of the entrepreneur is reflects predominant neoliberal discourses that tend to shift the burden of responsibility for care away from the state and onto individuals while privileging rationality, autonomy, choice and responsibility (Davies, 2005; Pinto, 2012).

Scholars have described the idealized, fictive entrepreneur a typically male "aggressive, competitive, solitary hero who aspires to the conquest of new markets" (Bruni, Gherardi \& Poggio, 2004, p. 426) and a warrior (Jones, 2014), consistent with Paul Martin's "conquer" metaphor described earlier. In these conceptions, neoliberalism privileges competitiveness as a coveted trait, while failing to acknowledge that it works against caring, inclusive, democratic communities (Hyslop-Margison, McKerracher, Cormier \& Desroches, 2007) and is at odds with AE (e.g., Julien, Wright \& Zinni, 2010) - serious shortcomings to postcolonial ideals.

AYEP operates within conventional institutional boundaries as high school credit courses and adheres to official policy grounded in neoliberal ideology. In fact, the corpus pointed to a Eurocentric canon as the basis of AYEP. Paul Martin's own description of the resources and program aims were as follows:

This country, if we are going to be able to compete with the Chinese, the Indians, if we are going to be able to hold our own in a world of huge populations far greater than ours, we cannot afford to waste a single talent.

...These are the first set of textbooks and workbooks that have ever been produced for indigenous people teaching high school business anywhere in the world. The purpose of this course is to teach these students about how to be entrepreneurs, how to be business people, how to basically do marketing and accounting, how to design an idea and then get it out and sell it (Tailfeathers, 2014, p. 3).

Martin's account was consistent with Mercredi's (2013) statement that "the program is designed to improve students' proficiency in Business Mathematics, English, Accounting, Marketing, and Information and Communications Technology, while supporting the acquisition of leadership skills.” Mercredi's (2013) Grade 11 course AYEP were: Challenge and Opportunity, Analyzing Ventures, Elements of a Venture Plan, Financing Ventures, Creating the Venture, and Project. The Grade 12 course modules are: E-Commerce, Expanding the Venture, Managing the Venture, Web Design, Promotion-Broadcast Advertising, and Project. These conform to the standard faire of the colonial entrepreneurial canon (Pinto, 2014).

Mercredi (2013) and TDSB (2014) provided examples of how the canon was realized in classrooms. AYEP's website, Mercredi (2013), and TDSB (2014) emphasized that students participating in AYEP would be paired with mentors. Mercredi (2013) outlined the role of the mentors as primarily assisting the student's effort to "write and refine a business plan and provide advice about pricing, budgets, advertising, and marketing" and website development, assisting the student in creating a "Trade Show display," "helping implement strategies for the growth of the student's venture," and finally, "encouraging the student to develop a passion for and commitment to the venture." These tasks suggest that the official terms of the mentoring relationship conform to the entrepreneurial canon, neglecting any overt discussion or assistance with talking about barriers, socio-cultural differences, or self-determination. While the nature of the mentee-mentor relationship can be meaningful and 
transformative, the parameters identified here suggest they may simply serve as a tool to reproduce hegemonic, colonial relations. ${ }^{5}$ Disrupting colonialism would require contrapuntal mentorship content, as well as ethical solidarity as outlined in the framework.

As described earlier, AYEP attempts to entice students with the possibility of a $\$ 500$ seed grant - neoliberal marketization in which education is reduced to a financial transaction. The requisite "pitch" reinforces corporate-friendly skills and attitudes consistent neoliberal discourses that conceal the darker side of capitalism reflecting White supremacy, and ignoring AE and IK. The irony is that the sources of the seed grants, and the decision-makers who evaluate the presentations, are representatives of banks who have historically ignored reserves (Brimble \& Blue, 2013; Kendall, 2001), and energy providers who continue to have controversial dealings with Aboriginal peoples (Friedel, 2008; Krupa, 2012). Through this practice, a neoliberal, assimilationist version of the fictive entrepreneur - a fast-talking deal-maker - is reinforced. By contrast, CRS would offer a more inclusive depiction of the entrepreneur, and possibly focus on educating those in positions of power (e.g., bankers) in critical reflection on stereotypes they hold about rhetorical style. A CRS pedagogy of "executive education" would also include attempts at building ethical solidarity rather than "civilizing" students to fit into existing entrepreneurial constructions (Brayboy, 2005; Cannon, 2013; Subedi, 2013).

The corpus revealed superficial attempts to incorporate IK in order to depart from a strictly Eurocentric epistemology. TDSB (2014) identified 3 elements in their AYEP program: case studies of successful Aboriginal business owners, a Medicine Wheel used as a graphic organizer, and the Seven Grandfather Teachings (wisdom, love, respect, bravery, honesty, humility and truth) as the courses' "philosophy of business." The limited materials available do not elaborate on the substantive content (e.g., which Aboriginal business owners are featured? Where and how are their narratives framed? How and in what situations is the Medicine Wheel applied? In what form do the Seven Grandfather Teachings appear in the courses?). However, when taken in context with other materials, these appear to amount to little more than rhetoric. This overt curriculum appears to place Aboriginal culture at the periphery, and certainly not a central part of that fictive entrepreneur's being as tokenist attempts to remedy representational injustice (Subedi, 2013). Such examples may be well-intentioned, but fall short of a postcolonial ideal, because examples fail to embody $\mathrm{AE}$ and the transformative view of self-determination defined by Brayboy (2005) and Battiste (2013). They neglect larger questions of systemic oppression, naturalizing them within "neoliberal ideology and corporate culture" (Subedi, 2013, p. 632). Adding cultural references onto the periphery of hegemonic practice is a form of epistemic violence (Subedi, 2013). By contrast, a postcolonial approach might rely on contrapuntal readings to engage in concerns and community-based aims grounded in IK that would equally acknowledge the realities of funding deficits in Aboriginal communities, and a critique of marketized systems and their history of oppression (e.g. Brayboy, 2005; Cherubini, 2010). Unless EE is re-centred in this way, Aboriginal learners and communities cannot reclaim the curriculum-as-material-property.

A neoliberal, marketized conception of the entrepreneur was further constructed through was course activity. Mercredi (2013) presented a photo of a gift basket titled, "Examples of hands-on classroom activities." The basket was wrapped in cellophane paper printed with colourful Easter eggs, with a white, self-adhesive bow on top. Plush toys were clearly visible as part of the basket's contents. The following explanation appeared next to the image: "Students will create a gift basket that they could sell" using MAEI-supplied materials. "Students determine selling price," the slide explained. "Profit goes back to the student with $10 \%$ going back to a charity of their choice." The focus on individual gain contradicts $\mathrm{AE}$ and community values about collective sharing 
of financial and other resources (e.g., Brimble \& Blue, 2013). The lack of Aboriginal values in financial content is yet another example of the absence of postcolonial approaches to AYEP's design.

Another slide also titled, "Examples of hands-on classroom activities" with a picture of Who wants to be a millionaire? contained the following list: "Games," "Fieldtrips (Banking activities)" and "Elevator Pitches." TDSB (2014) offered similar examples, naming "Help from the community" in the form of "Field trip locations (small businesses, franchises, large workplaces)," "Business clothing," and:

Students spend up to half a day at a bank or credit union to learn about the types of services these institutions provide

They learn how to open and maintain bank accounts, and how to comply with all required record keeping and other accountability measures

These pedagogies imply the fictive entrepreneur's central activity as dealing with financial institutions, and operating in assimilationist business conventions (rather than working toward a more inclusive model of entrepreneurship). The pedagogies appear to be in opposition to the Medicine Wheel and Grandfather Teachings allegedly guiding the course content. The production of a basket with un-necessary packaging contradicts respect for the environment. Neoliberal discourses silence any acknowledgement of the consumerist-materialist implications of contents of the basket in the photo, and the very theme of profiting over a solemn (and Eurocentric) holy day is problematic.

Neoliberal discourses often emphasize responsibilization and self-esteem, which shift responsibility for social problems from the state to the individual (Wright, 2012). By situating failure in the individual (deficit discourses), they encourage "passive student acceptance of existing economic, labour market, and social conditions" (Hyslop-Margison, McKerracher, Cormier \& Desroches, 2007, p. 5). For instance, an AYEP student was described as "typical of the students" - "when she arrived, she could not look a stranger in the eyes; the day she graduated, she stood, and in a strong confident voice, thanked the former PM for making all this possible" (Macgregor, 2008). A postcolonial approach would not attempt to change the student, but rather respect her ways of knowing, being and doing (Brayboy, 2005; Martin, 2003). Instead, ethical solidarity might be built by helping those in positions of power (teachers, AYEP program sponsors/partners) in checking their biases and overcoming stereotypes about "successful" or "appropriate" communication (Castagno \& Brayboy, 2008).

Aboriginal scholars critique and attempt to transform mainstream curriculum and pedagogy that socialize students into systems of knowledge that foster the sort of complacency in the example above (Battiste, 2013; Subedi, 2013). Rather than accepting the neoliberal "world as it is" and assimilate (like the student in the example), transformative postcolonial pedagogy aims for a curriculum of self-determination for Aboriginal peoples. Yet, the example reflected a neoliberal discursive tendency to allow labour markets to determine what counts as worthwhile knowledge and characteristics based on what is useful to industry rather than serving the needs of communities (Hyslop-Margison, McKerracher, Cormier \& Desroches, 2007, p. 7). Rather than respecting difference in the student (in fact, avoiding eye contact is a signifier of respect in many cultures), the discursive portrayal suggests that the student changed her way of knowing, being and doing through assimilationist practice that reinforced colonialism via White privilege and supremacy - and that such change is desirable.

One of the promises made by EE in general - and specifically in AYEP - is the neoliberal thesis that entrepreneurship is open and accessible to all, including the meritocratic view that personal effort determines reward and status (Ahl \& Marlow, 2012). If a person fails, then they did not put forth the requisite effort to "earn" the success. The problem is that meritocratic discourses make no mention of the role of luck 
(Kingwell, 2012), and more importantly, fail to acknowledge that capitalism guarantees poverty alongside massive wealth (Arthur, 2012). Yet, research has repeatedly revealed persistent but occluded biases in entrepreneurial discourse and practice that exclude oppressed groups (e.g., Ahl \& Marlow, 2012; Bruni, Gherardi \& Poggio, 2004; Welter, Brush, \& De Bruin, 2014). The corpus reported that Aboriginal workers were more likely to lose jobs and earn less in 2008-2009- but paid no attention to equity or systemic factors. Martin's own description of AYEP's objective was rooted in meritocracy: students will "understand that their choices become limitless, there is no restriction on their choices, if they get an education" (Adam, 2011). Cuthand (2011) characterized AYEP as "refreshing" because it focuses on what students can accomplish, "not the roadblocks." Yet, AYEP learners cannot avoid the "roadblocks" of White supremacy and privilege; failing to acknowledge them through contrapuntal readings is (at best) misleading, and at worst, potentially alienating when learners recognize a disconnect between their lived experiences and the overt curriculum in the absence of contrapuntal content (Brayboy, 2005).

AYEP's dominant neoliberal discourse failed to re-centre public attention on protracted systemic colonialism that desperately needs dismantling. It denied historical and contemporary issues of material, cultural and representational injustice that serve as very real barriers in the lives of Aboriginal peoples (Brayboy, 2005). Expecting Aboriginal entrepreneurs to merely "fit into" the existing economic system failed to support the transformation necessary to address structural inequities that perpetuate oppression and colonialism. Rather, postcolonial EE ought to interrogate social and epistemological differences as well as power relationships that influence knowledge production, what is considered legitimate curriculum and learning, and what constitutes just educational and social outcomes. This cannot be accomplished by wearing a business suit, selling Easter baskets, and playing Who Wants to be a Millionaire?

\section{Conclusion}

This research was the first to explore the AYEP program as a means of EE enactment. Discourses revealed the ways in which AYEP fell short of the postcolonial ideal, instead embodying neoliberal educational aims and practices through discourses that reinforce White privilege and supremacy. Problematic "official" program aims overtly positioned Aboriginal youth as Others while over-emphasizing benev(i)olent heroes on a civilizing mission to create colonized entrepreneurial prodigies subject to assimilation tactics in classrooms. Ironically, AYEP, like many other Aboriginal education programs that preceded it, "is the solution to a host of problems and complexities related to education, assimilation, compliance, and identity that was created by the colonial presence in the first place" (Cherubini, 2010, p. 19).

Troubling discourses revealed that AYEP attempted to occlude and erase inequity in ways that lead to neocolonial subjugation and sustain White supremacy. Moreover, strong emphasis on individual prosperity attempted to unify Aboriginal students' knowledge, behavior and attitudes with those of the dominant group without any real acknowledgement of difference. Superficial inclusion of AE and IK failed to create CRS that would be necessary to achieve postcolonial ideals.

A final issue, beyond the scope of this paper, but worthy of investigation, is whether Aboriginal EE should remain segregated, or mainstreamed to provide all learners with valuable AE and IK perspectives. Surely, all students would benefit from a more diverse curriculum that reflect a multitude of Canadian values, positions, successes and failures, while critiquing the hegemony embedded in conventional EE. This might address Battiste's (2013) call for Canadian people and institutions to view Aboriginal peoples "not as disadvantaged racial minorities but as distinct, historical and 
socio-political peoples within Canada with collective rights" (pp. 72-73). AYEP's segregated approach poses a particular challenge to building ethical solidary because non-Aboriginal learners and business leaders lack access to IK, AE and Aboriginal perspectives.

Systemic transformation cannot be achieved if only the marginalized are exposed to stories of oppression and the means necessary for a more socially just society (Brayboy, 2005; Subedi, 2013). A critical interrogation of the "promises" of entrepreneurship in general must take proponents to task about what EE can realistically achieve and the effects on those who undertake it as a career. It must also question whose interests are served when EE relies exclusively Eurocentric epistemologies. Rather, AYEP learners would be more justly served through a CRS-oriented program founded on antiessentialism, contrapuntal curricula, and ethical solidarity with peers, community members, and citizens-at-large.

\section{References}

Adam, B. A. (2011, October 22). Former PM opens doors for students; education imbalance slammed. Star-Phoenix. Retrieved from http://search.proquest.com/docview/900331870?accountid=14771

Ahl, H., \& Marlow, S. (2012). Exploring the dynamics of gender, feminism and entrepreneurship: Advancing debate to escape a dead end? Organization, 19(5), 543-562.

Arnot, M. (2006). Gender equality, pedagogy and citizenship: Affirmative and transformative approaches in the UK. Theory and Research in Education, 4(2), 131-150.

Arthur, C. (2012). Financial literacy education for citizens: What kind of responsibility, equality and engagement? Citizenship, Social and Economics Education, 11(3), 163-176.

Banerjee, S., \& Tedmanson, D. (2010). Grass burning under our feet: Indigenous enterprise development in a political economy of whiteness. Management Learning, 41(2) 147-165.

Battiste, M. (2013). Decolonizing education: Nourishing the learning spirit. Saskatoon, SK: Purich Publishing Limited.

Boler, M. (2004). Democratic dialogue in education: Troubling speech, disturbing silence. New York, NY: Peter Lang.

Brayboy, B. M. J. (2005). Toward a tribal critical race theory in education. The Urban Review, 37(5), 425-446.

Brimble, M., \& Blue, L. (2013). Tailored financial literacy education: An indigenous perspective. Journal of Financial Services Marketing, 18(3), 207-219.

Bruni, A., Gherardi, S., \& Poggio, B. (2004). Doing gender, doing entrepreneurship: An ethnographic account of intertwined practices. Gender, Work \& Organization, 11(4), 406-429.

Burch, P. (2010). Hidden markets: The new education privatization. London: Routledge.

Cannon, M. J. (2013). Changing the subject in teacher education: Centering Indigenous, diasporic, and settler colonial relations. Cultural and Pedagogical Inquiry, 4(2), 21-37.

Cardston Temple City Star. (2014, February 6). PM Martin visits Blood Tribe. Retrieved from: http://search.proquest.com/docview/1495401122?accountid=14771

Castagno, A. E., \& Brayboy, B. M. J. (2008). Culturally responsive schooling for Indigenous youth: A review of the literature. Review of Educational Research, 78(4), 941-993.

Cherubini, L. (2010). An analysis of Ontario Aboriginal education policy: Critical and interpretive perspectives. Mc Gill Journal of Education, 45(1).

Coduras, A., \& Autio, E. (2013). Comparing subjective and objective indicators to describe the national entrepreneurial context: the Global Entrepreneurship Monitor and the Global Competitiveness Index contributions. Investigaciones Regionales, 26, 47-74.

Colley, H. (2002). A rough guide to the history of mentoring from a Marxist feminist perspective. Journal of Education for Teaching: International research and pedagogy, 28(3), 257-273.

Cuthand, D. (2011, October 14). Martin initiative puts focus on positive future. Star-Phoenix. Retrieved from http://search.proquest.com/docview/898490781?accountid=14771

Davies, B. (2005). The (im)possibility of intellectual work in neoliberal regimes. Discourse: Studies in the Cultural Politics of Education, 26(1), 1-14.

Delgado, R. (2011).Rodrigo's reconsideration: Intersectionality and the future of critical race theory. Iowa Law Review, 96, 1247-1288.

European Communities. (2007). Key competences for lifelong learning: European reference framework. Luxembourg: Office for Official Publications of the European Communities.

Fairclough, N. (1992). Discourse and social change. Cambridge: Polity Press.

Fraser, N. (1997). Justice interruptus. New York: Routledge.

Friedel, T. L. (2008). (Not so) crude text and images: staging Native in 'big oil' advertising. Visual Studies, 23(3), 238-254.

Gillborn, D. (2005). Education policy as an act of white supremacy: Whiteness, critical race theory and education reform. Journal of Education Policy, 20(4), 485-505.

Hickling-Hudson, A. (2011). Teaching to disrupt preconceptions: education for social justice in the imperial aftermath. Compare, 41(4), 453-465. 
Hindle, K., \& Moroz, P. (2010). Indigenous entrepreneurship as a research field: developing a definitional framework from the emerging canon. International Entrepreneurship and Management Journal, 6(4), 357-385.

Hoekstra, G. (2011, Jan 13). Martin dreams of change for aboriginal youth. Prince George Citizen. Retrieved from http://search.proquest.com/docview/840282750?accountid=14771

Hyslop-Margison, E. J., McKerracher, A., Cormier, J., \& Desroches, S. (2007). The Depiction of Workplace Reality: Principles of Democratic Learning and New Brunswick's Youth Apprenticeship Program. Canadian Journal of Educational Administration and Policy, 62, 1-14.

Jones, S. (2014). Gendered discourses of entrepreneurship in UK higher education: The fictive entrepreneur and the fictive student. International Small Business Journal, 32(3) 237-258.

Julien, M., Wright, B. \& Zinni, D. (2010). Stories from the circle: Leadership lessons learned from Aboriginal leaders. The Leadership Quarterly, 21, 114-126.

Kanu, Y. (2003). Curriculum as cultural practice: Postcolonial imagination. Journal of the Canadian Association for Curriculum Studies, 1(1), 67-81.

Keddie, A., \& Niesche, R. (2012). 'It's almost like a White school now': Racialised complexities, Indigenous representation and school leadership. Critical Studies in Education, 53(2), 169-182.

Kendall, J. (2001). Circles of disadvantage: Aboriginal poverty and underdevelopment in Canada. American Review of Canadian Studies, 31(1-2), 43-59.

Kennedy, M. (2011a, Dec 30). Martin looks to give aboriginals new hope; former PM says Canada must help. Leader Post. Retrieved from http://search.proquest.com/docview/913242949?accountid=14771

Kennedy, M. (2011b, Dec 28). A mission to improve aboriginals' lives; 'I'm going to work on this until the day I die,' vows former PM martin. Edmonton Journal. Retrieved from $\mathrm{http}: / /$ search.proquest.com/docview/913122953?accountid=14771

Kennedy, M. (2011c, Dec 27). Paul martin is a man on a mission; aboriginal issue is the biggest moral and social issue Canada faces, former PM says. The Gazette. Retrieved from http://search.proquest.com/docview/913018947?accountid=14771

Kingwell, M. (2012). Throwing dice: Luck of the draw and the democratic ideal. PhaenEx, 7(1), 66-100.

Krupa, J. (2012). Identifying barriers to Aboriginal renewable energy deployment in Canada. Energy Policy, 42, 710 714.

Ladson-Billings, G. (1998). Just what is critical race theory, and what's it doing in a 'nice' field like education? International Journal of Qualitative Studies in Education, 11(1), 7-24.

Leonardo, Z. (2004). The color of supremacy: Beyond the discourse of 'white privilege.' Educational Philosophy and Theory, 36(2), 137-152.

Lingard, B. (2010). Policy borrowing, policy learning: Testing times in Australian schooling. Critical Studies in Education, 51(2), 129-147.

Macgregor, R. (2008, June 14). From the classroom to a world of possibility. The Globe and Mail. Retrieved from http://search.proquest.com/docview/382784543?accountid=14771

Martin, K.L. \& Mirraboopa, B. (2003) Ways of knowing, ways of being and ways of doing: a theoretical framework and methods for Indigenous re-search and Indigenist research. Journal of Australian Studies, 76, 203-214.

Mercredi, Father Patrick Science \& Technology Centre. (2013). Creating entrepreneurial opportunities for Aboriginal students. Retrieved from: http://fathermercredi.fmcschools.ca/files/FMAborginal-Entrepreneurship2013.pdf

Napoleon, V. (2005). Aboriginal self determination: Individual self and collective selves. Atlantis: Critical Studies in Gender, Culture \& Social Justice, 29(2), 31-46.

Mentorship for aboriginal youth; Questions and answers. (2011, September 26). National Post. Retrieved from http://search.proquest.com/docview/894568636?accountid=14771

National Post. (2013, May 23). Scotiabank boosts entrepreneurship. Retrieved from http://search.proquest.com/docview/1354599360?accountid=14771

Nordin, A. (2014). Crisis as a discursive legitimation strategy in educational reforms: A critical policy analysis. Education Inquiry, 5(1), 109-126.

Pinto, L.E. (2012). Curriculum reform in Ontario: 'Common Sense' processes and democratic possibilities. Toronto, ON: University of Toronto Press.

Pinto, L.E. (2013). When politics trump evidence: Financial literacy education narratives following the global financial crisis. Journal of Education Policy, 28(1), 95-120.

Pinto, L.E. (2014). The cultural myth of the entrepreneur: 2014 remix. Our Schools/Our Selves, 23(4), 23-34.

Pinto, L.E. \& Coulson, E. (2012). Social justice and the gender politics of financial literacy education. Canadian Journal of the Association for Curriculum Studies, 9(2), 54-85.

Revely, J. \& Down, S. (2009). Stigmatization and self-presentation in Austrailian entrepreneurial identity formation. In Hjorth, D. \& Steyaert, C. The politics and aesthetics of entrepreneurship: A fourth movements in entrepreneurship book, pp. 162-181. Cheltenham, UK: Edward Elgar Publishing Limited.

Revilla, A. T., Wells, A. S., \& Holme, J. J. (2004). 'We didn't see color': The salience of colorblindness in desegregated schools. In L. Weis, L.P. Pruitt \& A. Burns (Eds), Off white: Readings on power, privilege, and resistance, (2nd Ed, pp. 284-301). New York: Routledge.

Rizvi, F. (2005). Representations of Islam and education for justice. In W. Crichlow (Ed.). Race, identity, and representation in education, 167-178. London: Routledge.

Schumacher, K. (2008, October 15). Pilot program gets business ideas flying; students will be encouraged to start up businesses. Daily News. Retrieved from http://search.proquest.com/docview/358110807?accountid=14771

Subedi, B. (2013). Decolonizing the curriculum for global perspectives. Educational Theory, 63(6), 621-638.

Tailfeathers, R. (2014). Aboriginal youth entrepreneur program. Tsinikssini: Blood Tribe Administration Newsmagazine, 6(1), 3 .

Toronto District School Board (TDSB). (2014).Aboriginal Youth Entrepreneurship Project. Retrieved from: http:/www.tdsb.on.ca/Portals/0/Community/Community\%20Advisory\%20committees/ACAC/PaulMartinI nitiative.pdf 
van Dijk, T.A. (1993). Principles of critical discourse analysis. Discourse \& Society, 4(2), 249-283.

Welter, F., Brush, C., \& De Bruin, A. (2014). The gendering of entrepreneurship context (No. 01/14). Working Paper, Institut für Mittelstandsforschung (IfM) Bonn. Retrieved from: http://www.econstor.eu/bitstream/10419/95879/1/780765389.pdf

Wright, A. (2012). Fantasies of empowerment: mapping neoliberal discourse in the coalition government's schools policy. Journal of education policy, 27(3), 279-294.

\section{End notes}

${ }^{1}$ One of the authors viewed a teacher candidate's Grade 11 lesson that embodied a postcolonial contrapuntal approach through deep exploration of "triple bottom line" accounting. Traditional accounting recognizes profit/loss/net worth as the only measure of success, known as the "bottom line." A "triple bottom line" recognizing 3 measures of success: economic (profit/loss/net worth), social (e.g., treatment of employees) and environmental. After introducing triple-bottom line, she explained that valuation of a company's worth includes "intangible assets," such as logos or trademarked slogans. If McDonalds eliminated its golden arches, valuations would be negatively affected since the arches' value as intangible assets would be subtracted from worth. Students identified the high intangible asset value of racist athletic franchise logos (e.g., Washington Redskins, Cleveland Indians). They explored how conventional accounting would make it imprudent (or impossible in certain shareholder situations) to remove them, but triple bottom line accounting might justify elimination.

${ }^{2}$ While detailed examples are beyond the scope of this paper, Cannon (2013) offers numerous pedagogical examples to promote ethical solidarity in classrooms.

${ }^{3}$ The fact that textbooks are unavailable to the public and researchers because of AYEP's privatized development and enactment underscores problems associated with educational privatization and eliminating transparency of public goods (Burch, 2010).

4 "Red Apple" is a derogatory term that implies "Red on the outside, White on the inside:" an Aboriginal person who has internalized a Eurocentric point-of-view while rejecting Aboriginal ("Red") points-of-view (Cherubini, 2010).

${ }^{5}$ While beyond the scope of this brief paper, critical perspectives on mentoring (e.g., Colley, 2002) have suggested that mentors tend to operate uncritically and can reproduce the status quo by shepherding mentees into dominant practices. 